\title{
Scalable Synthesis of Carbon-Supported Platinum-Lanthanide and Rare-Earth Alloys for Oxygen Reduction
}

Roy, Claudie; Knudsen, Brian P.; Pedersen, Christoffer M.; Velazquez-Palenzuela, Amado ; Christensen, Leif H.; Damsgaard, Christian Danvad; Stephens, Ifan E. L.; Chorkendorff, Ib

\section{Published in:}

A C S Catalysis

Link to article, DOI:

10.1021/acscatal.7b03972

Publication date:

2018

Document Version

Peer reviewed version

Link back to DTU Orbit

Citation (APA):

Roy, C., Knudsen, B. P., Pedersen, C. M., Velazquez-Palenzuela, A., Christensen, L. H., Damsgaard, C. D., Stephens, I. E. L., \& Chorkendorff, I. (2018). Scalable Synthesis of Carbon-Supported Platinum-Lanthanide and Rare-Earth Alloys for Oxygen Reduction. A C S Catalysis, 8, 2071-2080.

https://doi.org/10.1021/acscatal.7b03972

\section{General rights}

Copyright and moral rights for the publications made accessible in the public portal are retained by the authors and/or other copyright owners and it is a condition of accessing publications that users recognise and abide by the legal requirements associated with these rights.

- Users may download and print one copy of any publication from the public portal for the purpose of private study or research.

- You may not further distribute the material or use it for any profit-making activity or commercial gain

- You may freely distribute the URL identifying the publication in the public portal 


\section{Scalable Synthesis of Carbon Supported Platinum -}

\section{Lanthanide and Rare Earth Alloys for Oxygen}

\section{Reduction}

Claudie Roy, ${ }^{a}$ Brian P. Knudsen, ${ }^{a}$ Christoffer M. Pedersen, ${ }^{a, b}$ Amado Velázquez-Palenzuela, ${ }^{a, b}$

Leif H. Christensen, ${ }^{b}$ Christian Danvad Damsgaard, ${ }^{c}$ Ifan E. L. Stephens, ${ }^{a, d}$ and Ib

Chorkendorff, ${ }^{a *}$

a Surface Physics and Catalysis, Department of Physics, Technical University of Denmark, DK2800 Kgs. Lyngby, Denmark

${ }^{\mathrm{b}}$ Center for Nano- and Micro technology, Danish Technological Institute (DTI), Gregersenvej, DK-2630 Taastrup, Denmark

${ }^{\text {c }}$ Center for electron nanoscopy, Department of Physics, Technical University of Denmark, DK2800 Kgs. Lyngby, Denmark

${ }^{\mathrm{d}}$ Department of Materials, Imperial College London, London, United Kingdom

Keywords: synthesis, rare earths, platinum, alloy, oxygen reduction reaction, proton exchange membrane fuel cell, nanoparticles 


\begin{abstract}
Platinum rare earth alloys have proven both active and stable under accelerated stability tests in their bulk polycrystalline form. However, a scalable method for the synthesis of high surface area supported catalyst of these alloys has so far not been presented. Herein we discuss the thermodynamics relevant for the reduction conditions of the rare earths to form alloys with platinum. We show how, the tolerances for water and oxygen severely limits the synthesis parameters and how under certain conditions the thermal reduction of YCl3 with $\mathrm{H} 2$ is possible from $500{ }^{\circ} \mathrm{C}$. From the insight gained, we synthesized a PtxY/C by modifying a Pt/C catalyst, and confirmed alloy formation by both x-ray diffraction and x-ray photoelectron spectroscopy measurements. These reveal crystalline intermetallic phases and the metallic state of yttrium. Without any optimisation to the method, the catalyst has an improved mass activity compared to the unmodified catalyst, proving the viability of the method. Initial work based on thermodynamic equilibrium calculations on reduction time show promise in controlling the phase formed by tuning the parameters of time, temperature and gas composition.
\end{abstract}




\section{INTRODUCTION}

Proton exchange membrane fuel cells (PEMFCs) are amongst the most promising renewable energy technologies, capable of producing electricity through electrochemical reactions of hydrogen and oxygen fuels at near room temperature $\left(<80^{\circ} \mathrm{C}\right)$ operating conditions ${ }^{1-4}$. However, the high platinum loading at the cathode side strongly limits the expansion of hydrogen vehicles on the market ${ }^{5}$. Over the years, the loading at the anode could be reduced to $0.05 \mathrm{mg} \mathrm{cm}^{-2}$. The major kinetic losses at the cathode side still results in a high loading of Pt, i.e. $0.4 \mathrm{mg} \mathrm{cm}^{-2}$ of Pt in a state-of-the-art fuel cell ${ }^{4}$. One of the tool available for improving the catalytic activity is to optimize the bond strength of the oxygen reduction intermediate (ORR $)^{6,7}$ to the catalyst's active sites. Amongst the materials studied, the alloys of Pt with late transition metal like Ni and Co demonstrate among the highest catalytic activity reported ${ }^{8-10}$. One of the pillars that made the fuel cell electric vehicles (FCEVs) possible is the commercial use of a Pt-Co alloy that significantly increases the mass activity of the catalyst compared to previous generation vehicles ${ }^{11}$. When implemented in fuel cells, alloys of Pt with early transition metal tend to dealloy over time ${ }^{12-14}$.

The less noble metal dissolves into the acidic electrolytes, first from the surface, and then from the bulk on the long term ${ }^{12,15}$. Even so, there a numerous recent studies that reports novel forms of PtNi based catalyst with outstanding activity and stability, in accelerated degradation tests ${ }^{8,10,16,17}$.

Another group of alloys pioneered in our group are that of Pt and lanthanide and/or rare earth elements ${ }^{18-20}$. It was suggested that the alloying energy, or the negative enthalpy of formation, could also be used as a descriptor for stability against dissolution for the Pt-based catalysts. These alloys, such as $\mathrm{Pt}_{\mathrm{x}} \mathrm{Y}$ and $\mathrm{Pt}_{\mathrm{x}} \mathrm{Gd}$, have been shown to be both active and stable in polycrystalline ${ }^{21}$, single cristal $^{22,23}$ and nanoparticulate forms obtained from magnetron sputtering ${ }^{24,25}$, with the increase in activity originating from a compressed Pt overlayer ${ }^{20}$. The more reactive solute metal 
will tend to dissolve in the acid electrolyte of a PEMFC, resulting in the formation of a thick and strained Pt overlayer ${ }^{20}$. The trade-off between this strained structure, and the optimisation of surface-to-bulk ratio obtained with small particle size explains the observed maximal mass activity of nanoparticles of $\mathrm{Pt}_{\mathrm{x}} \mathrm{Y}$ and $\mathrm{Pt}_{\mathrm{x}} \mathrm{Gd}$ at around 8-9 $\mathrm{nm}^{26}$. Technological limitations on the magnetron sputtering, i.e. the slow deposition rate and the production limited to a few nanograms, prohibit scale up production of mass selected nanoparticles of $\mathrm{Pt}_{\mathrm{x}} \mathrm{Y}$ and/or $\mathrm{Pt}_{\mathrm{x}} \mathrm{Gd}$, and impede their implementation into membrane electrode assembly. For this, a scalable chemical synthesis technique up to the gram-scale is needed. Chemical synthesis including lanthanide and/or rareearth elements is a real challenge partly because of the oxophilicity of these compounds. The significant difference in reduction potential of the different elements with the standard reduction potential of $\mathrm{Pt}^{2+} / \mathrm{Pt}$ being $+1.18 \mathrm{~V}$ vs those of the rare earths such as $\mathrm{Y}^{3+} / \mathrm{Y}$ at $-2.37 \mathrm{~V}^{27}$ is also a main obstacle in the alloying process.

Many attempted to chemically synthesized these nanoparticles ${ }^{28-34}$, but without showing any real evidence of Pt-Y alloy formation, i.e. x-ray diffraction spectrum only showing Pt peaks and/or no x-ray photoelectron spectroscopy analysis of the $\mathrm{Y} 3 \mathrm{~d}$ region. Kanady et al. are the first, to our knowledge, that showed clear formation of intermetallic $\mathrm{Pt}_{3} \mathrm{Y}$ nanoparticles. In that work, molten borohydride was both the reducing agent and reaction medium ${ }^{35}$. Unfortunately, the catalyst was not tested for the electrochemical reduction of oxygen, and the activity cannot be compared to the one reported by our model study.

Before being able to obtained $\mathrm{Pt}_{\mathrm{x}} \mathrm{Y} / \mathrm{C}$ via a thermal process, we tried other different types of synthesis method. It was reported that it is possible to synthetize gold-coated gadolinium nanoparticles by alkalide reduction ${ }^{36}$. With the ultimate goal of replacing $\mathrm{Au}$ with $\mathrm{Pt}$, we reproduced the protocol reported by Yan, C. et $a^{36}$. Even after many attempts, we observed that 
only a small portion of Gd was actually reduced and incorporated into the gold nanoparticles, while most of the core was made of Si coming from the glassware. We also investigated the cyanide reduction techniques reported by Lux and co-worker ${ }^{37}$. In their protocol, they used $\mathrm{Pt}(\mathrm{CN})_{2}$ and $\mathrm{Ce}\left(\mathrm{NO}_{3}\right)_{3} \cdot 6 \mathrm{H}_{2} \mathrm{O}$ as precursors that they mixed in water, and annealed in $\mathrm{H}_{2}$ to obtain $\mathrm{Pt}_{\mathrm{x}} \mathrm{Ce}$ alloy. By following the same procedure but substituting Ce- with Y-based precursor, we successfully obtained $\mathrm{Pt}_{\mathrm{x}} \mathrm{Y}$ powder. Unfortunately, we did not manage to optimize the powder to favour the formation of nanoparticles. Also, the large production of $\mathrm{Pt}_{\mathrm{x}} \mathrm{Y}$ alloy would certainly represents a safety concern as HCN is one of the by-products.

In this work, we successfully scale-up the synthesis of the intermetallic alloys of $\operatorname{Pt}_{\mathrm{x}} \mathrm{Y}$ nanoparticles supported on carbon on a gram scale. The alloy was obtained by annealing nanoparticles of $\mathrm{Pt} / \mathrm{C}$ with $\mathrm{YCl}_{3}$ in hydrogen atmosphere. We provide thermodynamic calculations of the thermal reduction of halide salts of the rare earth metals by hydrogen that represent an important step forward the understanding of Pt-lanthanide and rare-earth alloy formation. Using these calculations, it was also possible to predict the formation of the most active $\mathrm{Pt}_{\mathrm{x}} \mathrm{Y}$ crystalline phase. The structure of all alloys is confirmed by X-ray Diffraction Spectroscopy (XRD), X-ray Photoelectron Spectroscopy (XPS) and transmission electron microscopy (TEM) techniques. The catalyst was tested using a rotating disk electrode setup for the oxygen reduction reaction (ORR) in acid electrolyte. To our knowledge, it is the first time that $\mathrm{Pt}_{\mathrm{x}} \mathrm{Y} / \mathrm{C}$ alloy synthetized on a gram scale exhibit enhanced mass activity, when compared to commercially available supported Pt catalyst. The thermal synthesis method used for the synthesis lends itself to efficient control of the alloy phase formed and could be extend to other element of the lanthanide and rare earth family. 


\section{THEORITICAL CALCULATIONS}

As mentioned above, the energy gained by the rare earth elements upon alloying with Pt is close to $4 \mathrm{eV}$, which is much greater than that of the late transition metals that only gain around 0.25 $\mathrm{eV}^{19}$. However, the alloying energy gained by the rare earth and lanthanide elements when forming their respective oxide is close to $10 \mathrm{eV}^{26}$, making the oxidation the favoured reaction when in contact with any oxidizing agent. In this work, we investigate alloy synthesis using thermal reduction in an $\mathrm{H}_{2}$ atmosphere. We utilised the HSC Chemistry software package (version 6.1) developed by Outotec Technologies. The data related to Pt-rare-earth/lanthanide alloys was not part of the database, and was extracted from experimental studies where oxide precursors are reduced thermally to alloy with $\mathrm{Pt}^{38-41}$. The understanding of the reactivity of the rareearth/lanthanide precursors and oxides is crucial for the synthesis of Pt alloys. Because of the great ORR activity obtained from model $\mathrm{Pt}_{\mathrm{x}} \mathrm{Y}$ nanoparticles and thin films, we decided to start investigating that specific system. We have calculated the variation in Gibbs free energy for (1) the reduction of yttrium halides $\left(\mathrm{YHa}_{3}\right)$ and (2) yttriym oxide $\left(\mathrm{Y}_{2} \mathrm{O}_{3}\right)$ to form $\mathrm{Pt}_{5} \mathrm{Y}$ alloys. The reaction to form $\mathrm{Pt}_{5} \mathrm{Y}$, from $\mathrm{Pt}$ metal and $\mathrm{YHa}_{3}$ in $\mathrm{H}_{2}$ atmosphere is:

$$
5 \mathrm{Pt}+\mathrm{YHa}_{3}+\frac{3}{2} \mathrm{H}_{2}(g)=\mathrm{Pt}_{5} \mathrm{Y}+3 \mathrm{HHa}(g)
$$

And the reaction to reduce $\mathrm{Y}_{2} \mathrm{O}_{3}$ with $\mathrm{Pt}_{5} \mathrm{Y}$ is:

$$
5 \mathrm{Pt}+\frac{1}{2} \mathrm{Y}_{2} \mathrm{O}_{3}+\frac{3}{2} \mathrm{H}_{2}(g)=\mathrm{Pt}_{5} \mathrm{Y}+\frac{3}{2} \mathrm{H}_{2} O(g)
$$

The determination of the change in Gibbs free energy $(\Delta \mathrm{G})$ for the $\mathrm{Pt}_{5} \mathrm{Y}$ system obtained from $\mathrm{Y}_{2} \mathrm{O}_{3}$, and also $\mathrm{YI}_{3}, \mathrm{YF}_{3}$ and $\mathrm{YCl}_{3}$ is of great interest to find the conditions favouring the alloying process at the lowest temperature and most accessible experimental conditions. The $\Delta$ Gs related 
to the different precursors is shown in Figure 1a as function of temperature. The formation of $\mathrm{Pt}_{5} \mathrm{Y}$ with chlorides and iodides have similar $\Delta$ Gs whereas the reaction with fluorides and oxides have a more positive $\Delta \mathrm{G}$, ruling out the latter. However, even with $\mathrm{YI}_{3}$ and $\mathrm{YCl}_{3}$, temperatures above $1000^{\circ} \mathrm{C}$ are necessary to favour the alloying $(\Delta \mathrm{G} \leq 0)$, which seems problematic with nanoparticles as we want to avoid agglomeration. The way around this problem is to keep the reaction out of equilibrium by removing gas product, which enables the reaction to run at lower temperatures. The equilibrium partial pressure for gas product from halide precursors can be calculated by solving the following equation where $K_{\mathrm{HHa}}$ is the equilibrium constant for the reduction of Pt metal with YHa,$P$ is the pressure and $P_{\mathrm{H} 2}$ and $P_{\mathrm{HHa}}$ is the partial pressure of $\mathrm{H}_{2}$ and $\mathrm{HHa}$, respectively:

$$
K_{\mathrm{HHa}}=\frac{\left(\frac{P_{\mathrm{HHa}}}{P}\right)^{3}}{\left(\frac{{ }_{\mathrm{H}_{2}}}{P}\right)^{\frac{3}{2}}}
$$

Similarly, the sensitivity for $\mathrm{H}_{2} \mathrm{O}$ can be found from the relation between the equilibrium constant for reaction (2) and the partial pressure of water vapour $P_{\mathrm{H} 2 \mathrm{O}}$ and hydrogen $P_{\mathrm{H} 2}$ :

$$
K_{\mathrm{H}_{2} \mathrm{O}}=\left(\frac{\frac{P_{\mathrm{H}_{2} \mathrm{O}}}{P}}{\frac{P_{\mathrm{H}_{2}}}{P}}\right)^{\frac{z}{y}}
$$

The solutions to equation (3) and (4) are plotted for the Pt $t_{5} \mathrm{Y}$ system with 1 bar of $\mathrm{H}_{2}$ on Figure 1b. At $600^{\circ} \mathrm{C}$, the equilibrium partial pressure of $\mathrm{HCl}$ and $\mathrm{HI}$ is around 0.01 . The concentration/production of $\mathrm{HCl}$ and $\mathrm{HI}$ is directly linked to the alloying process. For such high partial pressure, the alloying process is fast and catalyst on a gram scale can be produced in an hour timescale. Preliminary results also shows that very little amount is converted below the melting point of the precursor (see Figure S2). For that reason, $\mathrm{YCl}_{3}\left(\mathrm{~m} . \mathrm{p} .721^{\circ} \mathrm{C}\right.$ ) is of greater interest than $\mathrm{YI}_{3}\left(\mathrm{~m} . \mathrm{p} .994^{\circ} \mathrm{C}\right)$. 
The determination of $\Delta G$ and the equilibrium constant for the alloying process can be extended to other chloride precursors. Figure S1a and b show the calculated values for the alloying of $\mathrm{Pt}_{\mathrm{x}} \mathrm{M}$, where $\mathrm{M}=\mathrm{Dy}, \mathrm{Tb}, \mathrm{Tm}, \mathrm{Sm}, \mathrm{Gd}, \mathrm{Ce}, \mathrm{La}$ and $\mathrm{Ca}$, as function of temperature. There is a general trend where "late" lanthanides have higher reaction constant and thus produce higher concentration of gas as side product compared with "early" lanthanides. Thus, for the "late” lanthanide, alloying rate enabling the production of grams of materials is possible at lower temperature.

Using the same approach, and assuming constant $\mathrm{H}_{2}$ pressure of $1 \mathrm{bar}$, the partial pressure of $\mathrm{HCl}$ for forming different crystal structure of $\mathrm{Pt}_{\mathrm{x}} \mathrm{Y}$ was calculated. The $\mathrm{H}_{2}$ partial pressure for the alloy formation of $\mathrm{Pt}_{5} \mathrm{Y}$ and $\mathrm{Pt}_{3} \mathrm{Y}$ is presented in Figure 2a. A lack of data restrained us from calculating the alloy formation of $\mathrm{Pt}_{2} \mathrm{Y}$. If the system is kept below the equilibrium partial pressure of hydrochloric acid the formation of alloy will proceed. In turn this entails that for a given partial pressure above the equilibrium for the $\mathrm{Pt}_{3} \mathrm{Y}$, but below the equilibrium for $\mathrm{Pt}_{5} \mathrm{Y}$ only the latter will be formed. From this, it is seen that $\mathrm{Pt}_{5} \mathrm{Y}$ has the highest equilibrium pressure. The same observation was made for all $\mathrm{Pt}_{5} \mathrm{M}$ alloy when compared with their respective $\mathrm{Pt}_{3} \mathrm{M}$ phase and thus the formed phase could be controlled by monitoring controlling the partial pressure of $\mathrm{HCl}$.

Because of the oxophilicity of the rare earths and lanthanide, it is worth discussing the effect of water and oxygen contamination which could potentially hinder alloy formation. When in contact with oxygen, rare earth and lanthanide elements will oxidize rather than alloy with Pt because of the more negative enthalpy of formation ( $10 \mathrm{eV}$ per atom). Thus, the oxygen concentration when annealing Pt with rare earth/lanthanide elements should be minimized. The maximum limit of $\mathrm{H}_{2} \mathrm{O}$ that can be in contact with $\mathrm{Y}_{2} \mathrm{O}_{3}$ is presented in Figure 1b. Below that $\mathrm{H}_{2} \mathrm{O}$ partial pressure, the reductive environment will inhibit the oxidation reaction and the alloying will still occur. Above the $\mathrm{H}_{2} \mathrm{O}$ partial pressure, the concentration is too high and the reducing atmosphere is not enough 
to inhibit the oxidation of the precursor or the Pt-based alloy. The $\mathrm{H}_{2} \mathrm{O} / \mathrm{O}_{2}$ concentration threshold increases with temperature, for example: it is about $2 \mathrm{ppm}$ at $600^{\circ} \mathrm{C}$ and about $50 \mathrm{ppm}$ at $800{ }^{\circ} \mathrm{C}$ for $\mathrm{Pt}_{5} \mathrm{Y}$ alloys. The higher limit is set by the difference in reaction rate for reduction of $\mathrm{YCl}_{3}$ and oxidation of $\mathrm{YCl}_{3}$ or $\mathrm{Pt}_{5} \mathrm{Y}$, due to the difference in equilibrium partial pressure limit which can be different by orders of magnitude as also seen on figure 1 . The reaction time can be calculated by assuming that the reactions are limited by the gas product $(\mathrm{HCl})$ removal (i.e. assuming chemical equilibrium at all times). As mentioned above, the limit is linked to the partial pressure level of $\mathrm{HCl}$ and the speed at which the gas product can be removed. In regime where the alloying is limited by the $\mathrm{HCl}$ partial pressure, we can approximate the reaction time by applying the ideal gas equation:

$$
n_{\mathrm{HCl}}=\frac{P_{\mathrm{HCl} Q t}}{R T}
$$

Where $n_{\mathrm{HCl}}$ is the moles of $\mathrm{HCl}$ gas, $P_{\mathrm{HCl}}$ the partial pressure of $\mathrm{HCl}$ from equation (3), Q gas flow, $\mathrm{t}$ time, $\mathrm{R}$ is the gas constant and $\mathrm{T}$ is the temperature of the gas where the flow is measured. From equation 1, we can relate the number of moles of $\mathrm{HCl}, \mathrm{Pt}_{x} \mathrm{Y}$ and Pt.

$$
\frac{1}{3} n_{\mathrm{HCl}}=n_{\mathrm{Pt}_{\mathrm{X}} \mathrm{Y}}=\frac{1}{x} n_{\mathrm{Pt}}=\frac{1}{x} \frac{w_{P t}}{m_{\mathrm{Pt}}}
$$

And associate the formation of $\mathrm{Pt}_{5} \mathrm{Y}$ to the ideal gas equation:

$$
t=\frac{3}{x} \frac{w_{P t} R T}{m_{\mathrm{Pt}} P_{\mathrm{HCl}} Q}
$$

Using Equation (7), it is possible to approximate the reaction time for the formation of $\mathrm{Pt}_{5} \mathrm{Y}$ and $\mathrm{Pt}_{3} \mathrm{Y}$ from $0.5 \mathrm{~g}$ Pt and excess of $\mathrm{YCl}_{3}$ in 1 bar of $\mathrm{H}_{2}$ flowing at $10 \mathrm{~mL} / \mathrm{min}$. This shows that $1 \mathrm{~g}$ of 50\%wt. Pt/C can be converted into $\mathrm{Pt}_{5} \mathrm{Y}$ and $\mathrm{Pt}_{3} \mathrm{Y}$ in about 50 min and 140 min respectively at 800 
${ }^{\circ} \mathrm{C}$ under these experimental conditions (Figure 2b). This simple model does not include kinetics effects nor mass transport limitations of the rare earth or lanthanide species into the bulk of the platinum. However, our main interest is in the region where the reaction is limited by the removal of gas product, as it enables control over the formed alloy phases.

From this, it is possible to conclude that $\mathrm{Pt}_{\mathrm{x}} \mathrm{Y}$ alloy formation with metallic $\mathrm{Pt}$ is feasible using chloride precursor in 1 bar $\mathrm{H}_{2}$ at temperature higher than $600{ }^{\circ} \mathrm{C}$. The reaction is sensitive to $\mathrm{H}_{2} \mathrm{O}$ and $\mathrm{O}_{2}$ which should be kept below $1 \mathrm{ppm}$ at $600{ }^{\circ} \mathrm{C}$ and $20 \mathrm{ppm}$ at $800{ }^{\circ} \mathrm{C}$, which can be achieved with Instrumental Grade Hydrogen and a leak free system.

\section{EXPERIMENTAL SECTION}

\section{Synthesis of $\mathrm{Pt} \mathbf{x}$ /C nanoparticles}

The high oxophilicity of the rare earth and lanthanide elements requires minimal to no air exposure. For that reason, handling of the chemicals prior to and after thermal reduction took place in a glovebox (Omni-Lab system, Vacuum Atmospheres, $<0.5 \mathrm{ppm}_{2},<0.5 \mathrm{ppm} \mathrm{H}_{2} \mathrm{O}$ ). A homemade gas-tight metal reactor was designed for the preparation of the $\mathrm{Pt}_{\mathrm{x}} \mathrm{Y} / \mathrm{C}$ nanoparticles, and a simplified version is presented on Figure 3. The stainless steel reactor was put into a split-tubular furnace. For gas handling, VCR valves on the reactor were used for connecting to the high vacuum gas wall where gas flows and composition were controlled. An iron catalyst was placed before the metal reactor to prevent water and/or oxygen from entering the reactor and reacting with the precursors. The system was operated at one bar and controlled by a pressure controller on the back end of the setup. The gas stream from the thermal reduction was passed by a glass capillary sniffer that allows direct transfer to a quadrupole mass spectrometer for monitoring of the products. 
Using the synthesis setup, the $\mathrm{Pt} / \mathrm{C}$ nanoparticles were first dried at $200^{\circ} \mathrm{C}$ in $100 \mathrm{~mL} \mathrm{H}_{2}$ for 6 hours to remove trace amount of $\mathrm{H}_{2} \mathrm{O}$ from air exposure. Once the drying procedure over, $\mathrm{YCl}_{3}$ was mixed to the $\mathrm{Pt} / \mathrm{C}$ nanoparticles. $\mathrm{YCl}_{3}$ was first dissolved into anhydrous acetonitrile $(99.8 \%$, Sigma-Aldrich, $<10 \mathrm{ppm} \mathrm{H}_{2} \mathrm{O}$ ) before the $\mathrm{Pt} / \mathrm{C}$ nanoparticles was added. The mixture was partially covered and stirred overnight, and a dry powder was obtained. An optimal mixing of the $\mathrm{YCl}_{3}$ precursor with the Pt/C nanoparticles is essential to improve the phase selectivity and limit the use of chloride precursor. For that reason, a ratio of Pt nanoparticles to $\mathrm{YCl}_{3}$ of 1.5:1 was used.

The dry powder was spread evenly in the middle of a graphite foil (99.8\%, Alfa Aesar, $0.254 \mathrm{~mm}$ ) before being introduced into the metal reactor. The graphite foil is used to avoid contact between the precursors and the metal reactor. Finally, the metal reactor was sealed with copper head gasket and connected to the stainless steel tubes. Helium was purged to the reactor at $10 \mathrm{~mL} / \mathrm{min}$ for 20 minutes. The reactor was then filled with hydrogen for 60 minutes at $100 \mathrm{~mL} / \mathrm{min}$. The hydrogen flow was kept at $100 \mathrm{~mL} / \mathrm{min}$ during the annealing procedure. The high $\mathrm{H}_{2}$ flow was selected based on the thermodynamic calculations. Hydrogen, a reducing gas, prevents the oxidation of the yttrium by $\mathrm{O}_{2}$ assuming minimal leaks in the setup. The temperature was monitored using a thermocouple placed in the middle of the furnace. The annealing temperature of $800^{\circ} \mathrm{C}$ was chosen in order to be slightly above the melting point of the $\mathrm{YCl}_{3}$ precursor (m.p. $721^{\circ} \mathrm{C}$ ) ${ }^{27}$ as explained above.

\section{Physical Characterizations}

Prior to any characterization the as-synthesized catalyst was acid washed $\left(0.1 \mathrm{M} \mathrm{HClO}_{4}\right)$ and water washed 3 times. When the $\mathrm{Pt}_{\mathrm{x}} \mathrm{Y} / \mathrm{C}$ nanoparticles are formed and exposed to air, the first few monolayers of yttrium oxidize and the surface becomes $\mathrm{Pt}_{\mathrm{x}}-\mathrm{Y}_{2} \mathrm{O}_{3} / \mathrm{C}$. As the $\mathrm{Y}_{2} \mathrm{O}_{3}$ is unstable in 
acid electrolyte, the surface is cleaned from the oxide layer using $0.1 \mathrm{M} \mathrm{HClO}_{4}$ resulting in the strain Pt overlayer with high activity for the ORR. The acid electrolyte and water also remove any unreacted traces of precursor. The acid and water washed is essential to identify metallic yttrium under the Pt overlayer using XPS. The catalyst was then recovered by suspension in ethanol and dried at $60{ }^{\circ} \mathrm{C}$.

Acid-washed $\mathrm{Pt}_{\mathrm{x}} \mathrm{Y} / \mathrm{C}$ catalysts were subjected to XRD analysis in order to confirm the formation of intermetallic compounds with a long-range ordered structure. For such purpose, the powder catalyst is loaded on a zero-background plate and mounted in the equipment (Panalytical X'Pert Pro/Empyrean) in a transmission spinner stage configuration. The angle $2 \theta$ was varied between 15 and $90^{\circ}$ in continuous mode. For each batch of measurements, a silicon reference was measured and used as calibration. Data treatment of the collected XRD patterns was performed with the Panalytical HighScore Plus software suite, which also provided the database with the experimental XRD patterns used as reference. Additional XRD patterns for comparison purpose were taken from the online Inorganic Crystal Structure Database (ICSD)-Karlsruhe and in-house measurements on polycrystalline alloy stubs from MaTeck® used in previous works. ${ }^{3,21}$

The catalysts were characterized using X-ray Photoelectron Spectroscopy (XPS) to further confirm the alloy formation over the oxide. The samples were mounted on carbon tape attached to aluminium foil for a better contact. XPS measurements were acquired under ultra-high vacuum (UHV) conditions $\left(<10^{-8}\right.$ millibar) in a Theta-Probe instrument (Thermo Scientific). This instrument is equipped with a monochromatized $\mathrm{Al} \mathrm{K} \alpha$ source (emission line at $1486.7 \mathrm{eV}$ ), and XPS spectra were obtained at an analyser pass energy of $100 \mathrm{eV}$. In all cases, the atomic concentrations were quantified by integration of the Pt 4f, Y 4d, O 1s and C 1s peaks after removal of a Shirley-type background. The scans were calibrated according to the C $1 \mathrm{~S}$ peak (284.6 eV). 
Reference XPS spectra for comparison were obtained from the NIST X-ray Photoelectron Spectroscopy Database and in-house measurements on polycrystalline alloy stubs from MaTeck®. The size distribution of the deposited nanoparticles was determined with ex situ TEM imaging (Tecnai T20 G2). The area of the nanoparticles on the pictures was measured manually using the software ImageJ. The diameter was estimated assuming perfectly spherical particles.

\section{Electrochemical characterizations}

The electrochemical experiments were carried out in a custom-made three-electrode glass cell at $23^{\circ} \mathrm{C}$ using the rotating disk electrode method ${ }^{42-45}$. Prior to the measurements all glassware was cleaned in piranha solution (98\% $\mathrm{H}_{2} \mathrm{SO}_{4}$ (Merck, Emsure) and 30\% $\mathrm{H}_{2} \mathrm{O}_{2}$ (Merck, Emsure), 3:1 $\mathrm{v} / \mathrm{v}$ ) for $24 \mathrm{~h}$ and rinsed several times with milli-Q water at $80^{\circ} \mathrm{C}$. The electrochemical cell includes the working electrode which was mounted on a Pine Instruments rotator, a Pt wire (Chempur, 99.9\%, 0.5 mm diameter) to act as a counter-electrode and an $\mathrm{Hg} \mid \mathrm{Hg}_{2} \mathrm{SO}_{4}\left(0.6 \mathrm{M} \mathrm{H}_{2} \mathrm{SO}_{4}\right)$ reference electrode (Schott Instruments), the latter being separated from the working electrode compartment using a ceramic frit. The electrochemical experiments were performed in $0.1 \mathrm{M} \mathrm{HClO}_{4}$ electrolyte (70\% $\mathrm{HClO}_{4}$, Merck, Suprapur and Millipore Milli-Q, resistivity $>18.2 \mathrm{M} \Omega \mathrm{cm}$, TOC $<3 \mathrm{ppb}$ ). The gasses used were supplied by AGA with Instrument 5.0 purity for $\mathrm{Ar}, \mathrm{N}_{2}$ and $\mathrm{O}_{2}$ gasses; Instrument 4.5 for the $\mathrm{H}_{2}$ gas and Instrument 3.7 for the $\mathrm{CO}$. All the potentials are reported versus the reversible hydrogen electrode (RHE) and corrected for Ohmic drop. The Ohmic resistance was determined from the fitted high-frequency intercept measured using electrochemical impedance

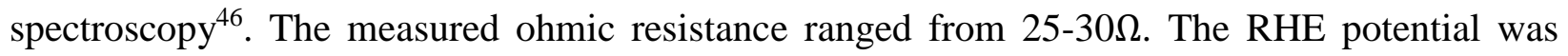
measured by bubbling $\mathrm{H}_{2}$ over the Pt electrode in the electrolyte at $1600 \mathrm{rpm}$ and measuring the mean of the intersection value while cycling the electrode from 0.02 to $0.3 \mathrm{~V}_{\mathrm{RHE}}$ at $10 \mathrm{mV} / \mathrm{s}$. 
The ink preparation of the $\mathrm{Pt} / \mathrm{C}$ catalyst was done as previously described ${ }^{43}$. The $\mathrm{Pt}_{\mathrm{x}} \mathrm{Y} / \mathrm{C}$ catalysts inks was based on isopropanol. A $5 \mathrm{~nm}$ in diameter glassy carbon electrode (Pine Instruments) was used as substrate. The glassy carbon disks were polished beforehand using Buehler MicroPolishTM 0.05 mm alumina particles on a Buehler MicroCloth PSA and then ultra-sonicated twice in both isopropanol and deionized water. The electrodes were prepared by first mounting the polished and cleaned glassy carbon disk in a custom-made Teflon holder, and then drop-casted 10 $\mu L$ with the prepared ink on a glassy carbon disk. The deposited aliquot is allowed to dry on air (or under a lamp heating up to $40-50{ }^{\circ} \mathrm{C}$ ) and then the electrode is coupled to a Pine Instruments rotating-disk electrode Teflon shaft that was attached to a rotator device (also from Pine) provided with a rotation speed controller upon the electrochemical measurement.

The working electrode was immersed into the electrochemical cell under potential control at 0.10 $\mathrm{V}_{\mathrm{RHE}}$ and cycled at $200 \mathrm{mV} / \mathrm{s}$ in a $\mathrm{N}_{2}$-saturated electrolyte until a stable $\mathrm{CV}$ was obtained (typically after ca. 200 cycles). Following this, the ORR performance of the $\mathrm{Pt}_{\mathrm{x}} \mathrm{Y} / \mathrm{C}$ catalysts was evaluated in $\mathrm{O}_{2}$-saturated solution at $50 \mathrm{mV} \mathrm{s}^{-1}$ and $1600 \mathrm{rpm}$ until a stable current was reached. The electrochemical surface area (ECSA) was evaluated using the CO-stripping method ${ }^{47}$. For this purpose, $\mathrm{CO}$ gas was first bubbled into the electrolyte for $2 \mathrm{~min}$, while the working electrode potential was kept at $0.05 \mathrm{~V}_{\mathrm{RHE}}$. The remaining $\mathrm{CO}$ dissolved in solution was removed by flushing Ar for 15 min whereas keeping the potential control. Afterwards, the potential was scanned up to $1.00 \mathrm{~V}$ in CO-free Ar-purged solution at $50 \mathrm{mV} \mathrm{s}^{-1}$. The corresponding electrochemical active surface area (ECSA) of the $\mathrm{Pt}_{\mathrm{x}} \mathrm{Y} / \mathrm{C}$ catalysts was estimated assuming a ratio of $420 \mu \mathrm{C} \cdot \mathrm{cm}^{-2}{ }^{48}$, for consistency reasons with previous works $25,26,49$. 


\section{RESULTS AND DISCUSSIONS}

\section{Physical and chemical characterizations}

As presented earlier, specific $\mathrm{Pt}_{\mathrm{x}} \mathrm{Y}$ phase can be thermodynamically favoured, and the progression can be monitored using the partial pressure of $\mathrm{HCl}$ (equation 7). In the aim of testing this theory, $\mathrm{Pt}_{\mathrm{x}} \mathrm{Y}$ were synthetized using 2 different annealing times (Table 1). An annealing of $360 \mathrm{~min}$ at $800^{\circ} \mathrm{C}$ was chosen and compared with a 60 min annealing time. The shorter treatment was chosen based on the production of $\mathrm{HCl}$ detected by the MS placed at the end of the reactor.

Figure 4 shows the mass spectrum signals of some of the products detected by the mass spectrometer while performing a synthesis. The zero value of the time scale was calibrated with the beginning of the annealing treatment. The temperature ramping is also presented (blue dashed line). $\mathrm{H}_{2}$ and $\mathrm{HCl}$ are presented as both products are involved in the alloy formation reaction (equation 1). The most abundant isotope of chlorine being 35, we expect that production of $\mathrm{HCl}$ should be detected when monitoring $\mathrm{m} / \mathrm{z}=36 . \mathrm{H}_{2}$ is correlated with a signal $\mathrm{m} / \mathrm{z}$ of 2 . The elevated $\mathrm{H}_{2}$ signal detected corresponds to the high flow of $100 \mathrm{~mL} \mathrm{H} / \mathrm{min}$ used during the annealing process.

Detection of molecular weight 36 can also be related to the detection of tricarbon anion $\left(\mathrm{C}_{3}{ }^{-}\right)$, a transient specie often observed in combustion reaction. To dissociate $\mathrm{HCl}$ production to combustion related product, $\mathrm{CO}_{2}(\mathrm{~m} / \mathrm{z}=44)$ is also plotted. $\mathrm{m} / \mathrm{z}=44\left(\mathrm{CO}_{2}\right)$ and $\mathrm{m} / \mathrm{z}=36(\mathrm{HCl})$ show much lower current intensity when compared with $\mathrm{m} / \mathrm{z}=2\left(\mathrm{H}_{2}\right)$. For both species, 2 more intense features are observed over the annealing period. For $\mathrm{m} / \mathrm{z}=44\left(\mathrm{CO}_{2}\right)$, a sharp peak is detected at $\mathrm{t}=9$ min, and a shoulder between $\mathrm{t}=63$ and $85 \mathrm{~min}$. A much small peak is observed at $\mathrm{t}=11 \mathrm{~min}$ for $\mathrm{m} / \mathrm{z}=36$ ( $\mathrm{HCl})$ but rather intense and broad peak is noted at ca. $\mathrm{t}=65 \mathrm{~min}$. For both $\mathrm{m} / \mathrm{z}=44\left(\mathrm{CO}_{2}\right)$ 
and $36(\mathrm{HCl})$, the decrease in signal from the second peak seems to be correlated to the furnace being stopped and hydrogen being replace by Helium. A drastic decrease is observed when the hydrogen flow and furnace are switched off. The mass spectrum signals of all detected species is available in SI.

The surface composition of the synthetized catalysts was characterized by XPS. In Figure 5 are displayed Pt $4 \mathrm{f}$ and $\mathrm{Y}$ 3d detail scans of the acid and water washed $\mathrm{Pt}_{\mathrm{x}} \mathrm{Y}$ annealed for $360(\mathrm{~A})$ and 60 (B) minutes respectively. As observed previously, the Pt 4f signal of a $\mathrm{Pt}_{\mathrm{x}} \mathrm{Y}$ alloy remain unchanged when compared to bare Pt. Indeed, the main Pt peaks of the $4 \mathrm{f}$ core level region at 71.4 eV indicate a metallic state for both samples. The XPS spectrum of the Y 3d core-level region was deconvoluted by more than a single set of peaks, which suggests that $\mathrm{Y}$ is in more than one chemical state. The deconvolution of the $\mathrm{Y}$ 3d from the long-term annealed $\mathrm{Pt}_{\mathrm{X}} \mathrm{Y}$ shows contribution of 3 different oxidation states of $\mathrm{Y}$ including $\mathrm{Pt}_{\mathrm{x}} \mathrm{Y}(156.4 \mathrm{eV}), \mathrm{Pt}_{3} \mathrm{Y}(155.3 \mathrm{eV})$ and $\mathrm{Y}_{2} \mathrm{O}_{3}(\mathrm{eV})$. The peak at $156.4 \mathrm{eV}$ was also observed when measuring on the $\mathrm{Pt}_{\mathrm{x}} \mathrm{Y}$ mass-selected nanoparticles $^{25}$ and associated to alloy formation between yttrium and platinum. A small Si contamination $(153.7 \mathrm{eV})$ is also observed in the $\mathrm{Y} 3 \mathrm{~d}$ region. This contamination was further confirmed by a peak a very small intensity around $103 \mathrm{eV}$. We suspect that this contamination came from the mixing of $\mathrm{Pt} / \mathrm{C}$ nanoparticles and $\mathrm{YCl}_{3}$ in a glass beaker. On the other hand, the deconvolution of the $\mathrm{Y} 3 \mathrm{~d}$ region from the $\mathrm{Pt}_{\mathrm{x}} \mathrm{Y}\left(60 \mathrm{~min}\right.$ at $800^{\circ} \mathrm{C}$ ) (Figure $\left.5 \mathrm{~B}\right)$ shows a mix of $\mathrm{Pt}_{\mathrm{X}} \mathrm{Y}(156.4 \mathrm{eV})$ and $\mathrm{Y}_{2} \mathrm{O}_{3}(158.3 \mathrm{eV})$. The Pt:Y ratio varies between 3.5 and 3.9 for the long- and short-term synthesis, respectively. Similarly, the XPS spectra of the Y 3d region of the $\mathrm{Pt}_{3} \mathrm{Y}$ obtained from the molten reducing agent method ${ }^{35}$ after acid washed shows $\mathrm{Y}_{2} \mathrm{O}_{3}$ and metallic $\mathrm{Y}$. Unlike what we report, they could only identify one metallic Y specie. 
Intermetallic phase formation for the $\mathrm{Pt}_{\mathrm{x}} \mathrm{Y}$ catalysts obtained by high temperature synthesis was also confirmed by XRD (Figure 6). The comparison of the XRD pattern of the as-received Pt/C reference (black line) and the synthetized catalyst (dark and light grey lines) show many discrepancies ensuring that no metallic Pt is contained in the synthetized catalyst. Indeed, if we compare the long-term synthesis with the Pt/C reference, we observe that even though the peak at $39.7^{\circ}$ could be related to the (111) Pt reflection, no other peaks related to the Pt reference are observed. The crystalline structure of the $\mathrm{Pt}_{\mathrm{x}} \mathrm{Y}$ annealed for 360 minutes shows reflections associated to 3 different $\mathrm{Pt}_{\mathrm{x}} \mathrm{Y}$ phase. The identification of the measured reflections was done based on previous work ${ }^{3}$ where bulk polycrystalline $\mathrm{Pt}_{2} \mathrm{Y}, \mathrm{Pt}_{5} \mathrm{Y}$ and $\mathrm{Pt}_{3} \mathrm{Y}$ were characterized. $\mathrm{The} \mathrm{Pt}_{3} \mathrm{Y}$ show intense peaks at $38.3^{\circ}, 44.5^{\circ}$ and $64.4^{\circ}$ associated to the (111), (002) and (022) planes respectively. A face centre cubic (FCC) $\mathrm{Pt}_{5} \mathrm{Y}$ from the crystal prototype $\mathrm{AuBe}_{5}{ }^{3}$ is also observed and show characteristic peaks at $39.7^{\circ}((113)$ facets $)$ and $41.42^{\circ}\left((222)\right.$ facets). Finally, the $\mathrm{Pt}_{2} \mathrm{Y}$ phase shows low intensity peak for the (004) plane at $47.8^{\circ}$. The XRD pattern of the $\mathrm{Pt}_{\mathrm{x}} \mathrm{Y}$ obtained from short annealing only shows reflections associated to the FCC and/or hexagonal $\mathrm{Pt}_{5} \mathrm{Y}$, from the prototype structure $\mathrm{Cu}_{5} \mathrm{Ca}$. The most intense peak at $40.0^{\circ}$ could be related to the (111) reflection of the FCC and/or hexagonal $\mathrm{Pt}_{5} \mathrm{Y}$. A shoulder fitting with the position of the (002) facets of the hexagonal $\mathrm{Pt}_{5} \mathrm{Y}$ is noted. Also, many less intense peak associated to the $\mathrm{Pt}_{5} \mathrm{Y}$ is observed at higher degrees of reflection. Many of the FCC and hexagonal structure are overlapping making it difficult to fully differentiate. The carbons support shows a peak on all the XRD pattern at $25.8^{\circ}$.

The particle-size distribution (PSD) histograms of the catalysts were determined using TEM and are plotted in Figure 7. The $\mathrm{Y}$ axis plotted is the percentage volume of nanoparticles of a specific size. This value was obtained from the number of nanoparticles for a define size multiply by its 
volume. From Figure 7a, it is observed that the as received $\mathrm{Pt} / \mathrm{C}$ catalyst has already a relatively broad size distribution with an average of $7.6 \pm 3.4 \mathrm{~nm}$. Only one big particle ( $35 \mathrm{~nm})$ was observed but is not represented on the TEM picture. The average of the $\mathrm{Pt}_{\mathrm{x}} \mathrm{Y} / \mathrm{C}$ nanoparticles obtained from the short-term synthesis is slightly higher than for the as received Pt particles with a PSD of $9.9 \pm 3.6 \mathrm{~nm}$. We can count that for this catalyst $\sim 80 \%$ of the particles have diameter size $>10 \mathrm{~nm}$. The $\mathrm{Pt}_{\mathrm{x}} \mathrm{Y} / \mathrm{C}$ synthesis obtained from 360 min annealing shows the highest PSD (12.1 \pm $4.4 \mathrm{~nm}$ ), and $\sim 92 \%$ of the nanoparticles have particle diameter above $10 \mathrm{~nm}$.

\section{Oxygen Reduction Reaction}

The activity for oxygen reduction of the $\mathrm{Pt}_{\mathrm{x}} \mathrm{Y}$ catalysts is presented in Figure 8. Typical cyclic voltammograms in $\mathrm{O}_{2}$-saturated $0.1 \mathrm{M} \mathrm{HClO}_{4}$ solution at $50 \mathrm{mVs}^{-1}$ are shown on Figure 8a. The $\mathrm{Pt} / \mathrm{C}$ nanoparticles used for the synthesis was measured and used as reference. We chose the Pt/C nanoparticles to compare the catalytic activity of PtxY catalysts with similar nanoparticle sizes. Comparison with commercial Pt/C TKK 60\% is also available in SI (Figure S3). In the potential region of mixed kinetic and mass transport, there is a positive shift for the longer annealed $\operatorname{Pt}_{\mathrm{X}} \mathrm{Y}$ nanoparticles, relative to Pt. This represents a substantial decrease in the overpotential for the alloy surface. The kinetic activity at $0.9 \mathrm{~V}_{\mathrm{RHE}}$ normalised by the specific surface area and mass fraction of platinum is plotted in Figure 9b and 9c, respectively. As expected, the activity reported for our $\mathrm{Pt} / \mathrm{C}$ reference catalyst is lower than the state-of-the-art Pt/C nanoparticles reported previously ${ }^{43}$. The lower kinetic activity of the Pt/C electrode measured in this work is related to the bigger particles size of the Pt catalyst ${ }^{49}$. The largest increase in specific and mass activity is obtained with the $\mathrm{Pt}_{\mathrm{x}} \mathrm{Y}$ annealed during $360 \mathrm{~min}$ at $800^{\circ} \mathrm{C}$. An increase in mass activity, the most relevant activity descriptor when considering the implementation into fuel cell device, of roughly $40 \%$ compared 
to our $\mathrm{Pt} / \mathrm{C}$ reference is showed. Very similar mass activity is obtained with the $\mathrm{Pt}_{\mathrm{x}} \mathrm{Y}$ nanoparticles annealed for $60 \mathrm{~min}$ at $800^{\circ} \mathrm{C}$.

\section{Discussion}

XPS results show that intermetallic $\mathrm{Pt}_{\mathrm{x}} \mathrm{Y}$ was successfully formed. For both catalyst, $\mathrm{Pt}_{\mathrm{x}} \mathrm{Y}$ was observed. A $\mathrm{Pt}_{3} \mathrm{Y}$ phase, corresponding to the respective XRD pattern was also observed for the $\mathrm{Pt}_{\mathrm{x}} \mathrm{Y} / \mathrm{C}$ annealed for 360 min. The metallic Pt peaks observed for both $\mathrm{Pt}_{\mathrm{x}} \mathrm{Y}$ catalyst is what previously reported for Pt-Y alloy formation ${ }^{25}$. The ratio of Pt and Y signal of 3.5 to 3.9 corresponds to the values already reporter for the formation of a "thick" Pt overlayer due to yttrium oxidation and leaching once exposed to air and acid electrolyte ${ }^{25}$. We don't expect the small Si contamination to influence the catalyst performance. The XRD patterns of the synthesised $\operatorname{Pt}_{\mathrm{X}} \mathrm{Y}$ nanoparticles confirm the alloy formation, and prove that the annealing time impact the $\operatorname{Pt}_{\mathrm{x}} \mathrm{Y}$ phases formed. We argue that the differences in phase formation with annealing time can be explained by our thermodynamic considerations as we predicted that the $\mathrm{Pt}_{3} \mathrm{Y}$ phase takes longer time to form than the $\mathrm{Pt}_{5} \mathrm{Y}$. From XRD data, no metallic Pt was observed meaning that it all reacted with the $\mathrm{YCl}_{3}$ precursor at $800^{\circ} \mathrm{C}$.

We hypothesis that the lower specific and mass activity obtained for $\mathrm{Pt}_{\mathrm{x}} \mathrm{Y}$ catalysts is mainly caused by 2 factors: the nature of $\mathrm{Pt}_{\mathrm{x}} \mathrm{Y}$ phase and the nanoparticles sizes. The nature of $\mathrm{Pt}_{\mathrm{x}} \mathrm{Y}$ phase impacts strongly the kinetic activity towards the oxygen reduction. Indeed, $\mathrm{Pt}_{3} \mathrm{Y}$ is the most active $\mathrm{Pt}_{\mathrm{x}} \mathrm{Y}$ phase, reaching $9.4 \mathrm{~mA} / \mathrm{cm}^{2} \mathrm{Pt}$ at $0.9 \mathrm{~V}_{\mathrm{RHE}}$ and outperforming $\mathrm{Pt}_{5} \mathrm{Y}$ by a factor of $1.6{ }^{3}$, as

previously reported. As reported by Escudero-Escribano and co-workers ${ }^{20}$ that shorter Pt-Pt bonds at the surface of the thick Pt overlayer is the main responsible of the increase in activity. It was also reported that $\mathrm{Pt}_{2} \mathrm{Y}$, which activity similar to one of Pt corrodes after only few cycles in $0.1 \mathrm{M}$ 
$\mathrm{HClO}_{4}$, and end up with catalytic activity similar to Pt. The size study made for $\mathrm{Pt}_{\mathrm{x}} \mathrm{Y}$ showed that the kinetic activity and particle size are closely linked and that maximal performance is expected for particles having 8-9 $\mathrm{nm}$ in diameter ${ }^{25}$. Indeed the highest mass and specific activity reported for this system is of $3.1 \mathrm{~A} / \mathrm{mg}_{\mathrm{Pt}}$ and $13.5 \mathrm{~mA} / \mathrm{cm}^{2} \mathrm{Pt}$, respectively, at $0.9 \mathrm{~V}_{\mathrm{RHE}}$. In our work, we demonstrated that $\sim 80 \%$ and $\sim 92 \%$ of the $\mathrm{Pt}_{\mathrm{x}} \mathrm{Y}$ particles obtained from $60 \mathrm{~min}$ and $360 \mathrm{~min}$ annealing, respectively, have particle diameter bigger than $10 \mathrm{~nm}$. This considerable proportion of nanoparticles with larger diameter contribute to lower significantly the activity measured, and explain why only $0.43 \mathrm{~A} / \mathrm{mg}_{\mathrm{Pt}}$ and $2.0 \mathrm{~mA} / \mathrm{cm}^{2} \mathrm{Pt}$ were measured at $0.9 \mathrm{~V}_{\mathrm{RHE}}$. The remaining volume having particle sizes between $2 \mathrm{~nm}$ to $9 \mathrm{~nm}$ have mass activities that varies between one similar to a 6-fold improvement in comparison to Pt.

\section{CONCLUSIONS}

In conclusion, the thermodynamics of the reaction conditions of Pt and rare earth/lanthanide chloride precursors in an $\mathrm{H}_{2}$ atmosphere at high temperature helped us establishing the conditions for alloy formation. The synthesis procedure was applied to Pt-Y catalysts because of the lower annealing temperature required, and the already establish high activity for the oxygen electroreduction. XRD and XPS pattern showed clear formation of Pt-Y alloy phases, and demonstrated the impact of the annealing time on the phase formation, which also correlates with the thermodynamic calculations. The particle size distribution done using TEM images showed relatively large distribution caused by the inhomogeneous size of Pt/C nanoparticles used for the synthesis and the annealing at $800^{\circ} \mathrm{C}$ that favor sintering. The electrochemical testing for the oxygen reduction reaction show for the first time with catalysts synthesised on a gram scale, 
improved catalytic activity. The lower mass activity of the thermally synthesized nanoparticles compared with the mass selected $\mathrm{Pt}_{\mathrm{x}} \mathrm{Y}$ can be explained by the too big average particle size and the nature of the $\mathrm{Pt}_{\mathrm{x}} \mathrm{Y}$ crystalline phase. The method used for the synthesis of Pt-Y nanoparticles can easily be extended to other rare earth and lanthanide based on the thermodynamic data and clear experimental procedure presented. Decreasing the nanoparticle size distribution, favouring $\mathrm{Pt}_{3} \mathrm{Y}$ alloy phase formation and testing the catalyst in experimental conditions closer to fuel cells operating conditions, i.e. at higher current densities ${ }^{50-52}$ or in a membrane electrode assembly, are part of the ongoing experiments for extended catalyst application.
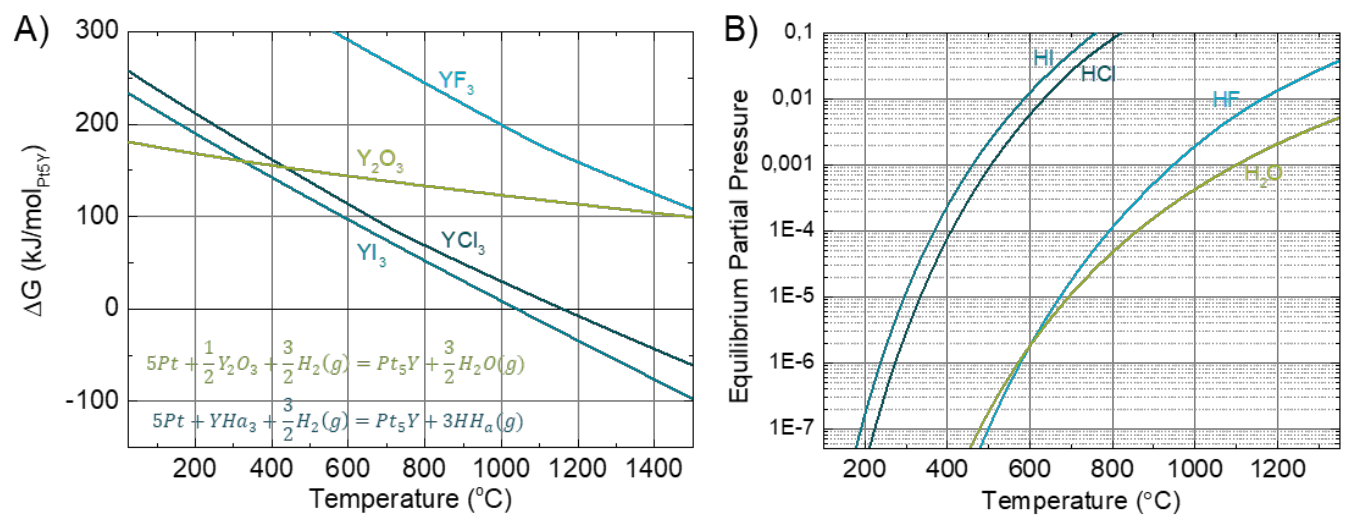

Figure 1. A) Calculated variation in Gibbs free energy for forming $\mathrm{Pt}_{5} \mathrm{Y}$ by annealing $\mathrm{Pt}$ assuming 1 bar $\mathrm{H}_{2}$ with $\mathrm{Y}_{2} \mathrm{O}_{3}, \mathrm{YF}_{3}, \mathrm{YCl}_{3}$ and $\mathrm{YI}_{3}$ and $\mathrm{B}$ ) respective equilibrium partial pressure of gas products generated by the alloying process. 

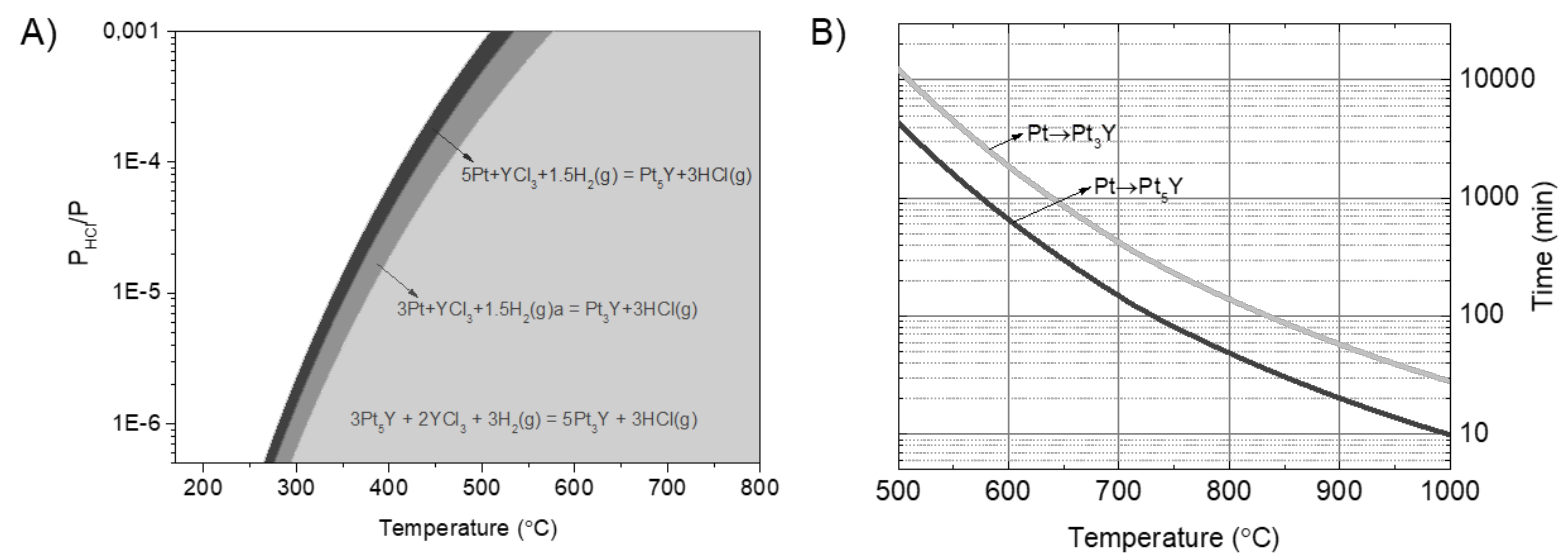

Figure 2. A) Phase formation of $\mathrm{Pt}_{3} \mathrm{Y}$ and $\mathrm{Pt}_{5} \mathrm{Y}$ as function of $\mathrm{P}_{\mathrm{HCl}} / \mathrm{P}$ and temperature. Not enough data allowed us to calculate phase formation of $\mathrm{Pt}_{2} \mathrm{Y}$. B) Expected reaction time for $0.5 \mathrm{~g} \mathrm{Pt}$ in $10 \mathrm{Ml} / \mathrm{min} \mathrm{H}_{2} 100 \% \mathrm{H}_{2}$ 


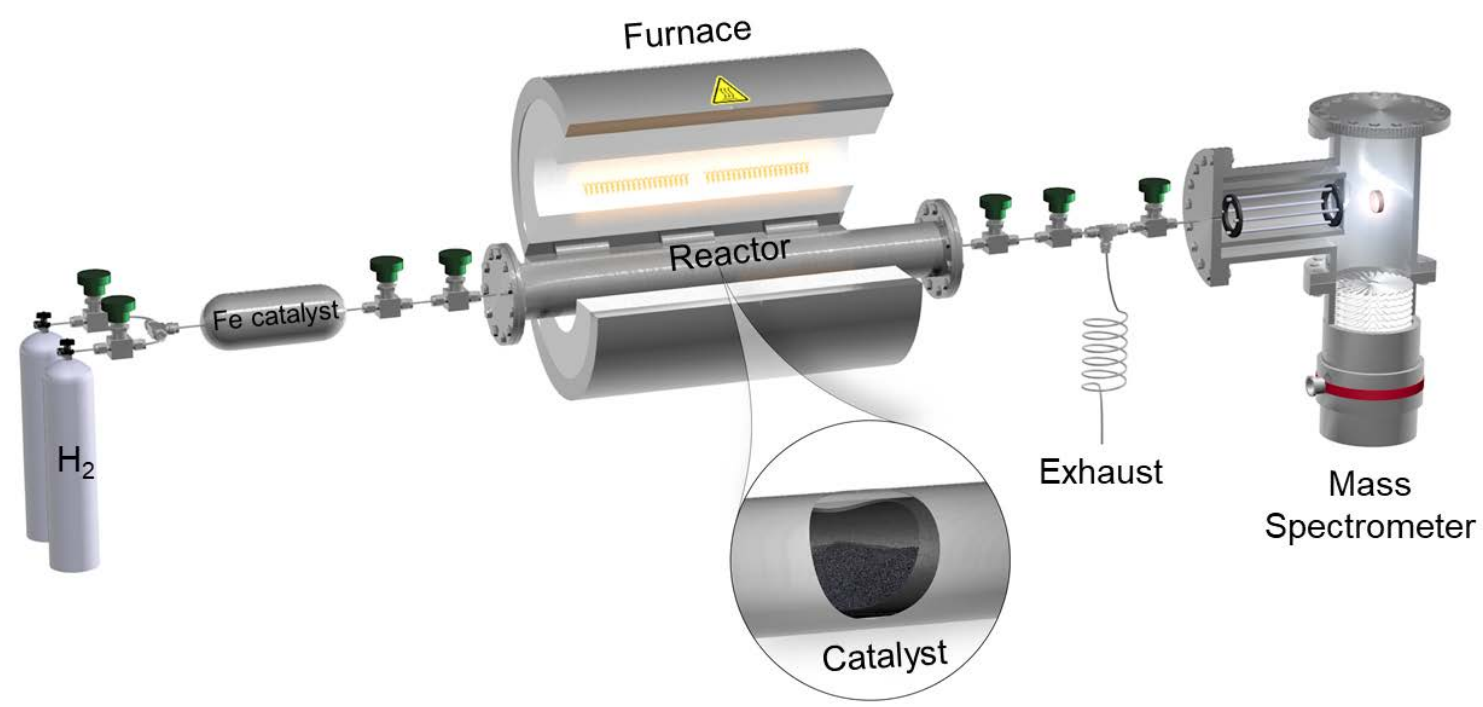

Figure 3. Metal reactor setup used for the high temperature synthesis of $\mathrm{Pt}_{\mathrm{x}} \mathrm{Y} / \mathrm{C}$ nanoparticles 


\begin{tabular}{|c|c|c|c|c|}
\hline \multirow{2}{*}{ Experiments } & \multicolumn{4}{|c|}{ Duration steps } \\
\cline { 2 - 5 } & $25^{\circ} \mathrm{C} \rightarrow 400^{\circ} \mathrm{C}$ & $400^{\circ} \mathrm{C} \rightarrow 600^{\circ} \mathrm{C}$ & $600^{\circ} \mathrm{C} \rightarrow 800^{\circ} \mathrm{C}$ & $800^{\circ} \mathrm{C}$ \\
\hline Short-term annealing & 10 min & 20 min & 30 min & $\mathbf{6 0}$ min \\
\hline Long-term annealing & 10 min & 20 min & 30 min & 360 min \\
\hline
\end{tabular}

Table 1. Parameters of the thermal treatment for the synthesis of $\mathrm{Pt}_{\mathrm{x}} \mathrm{Y} / \mathrm{C}$ nanoparticles 


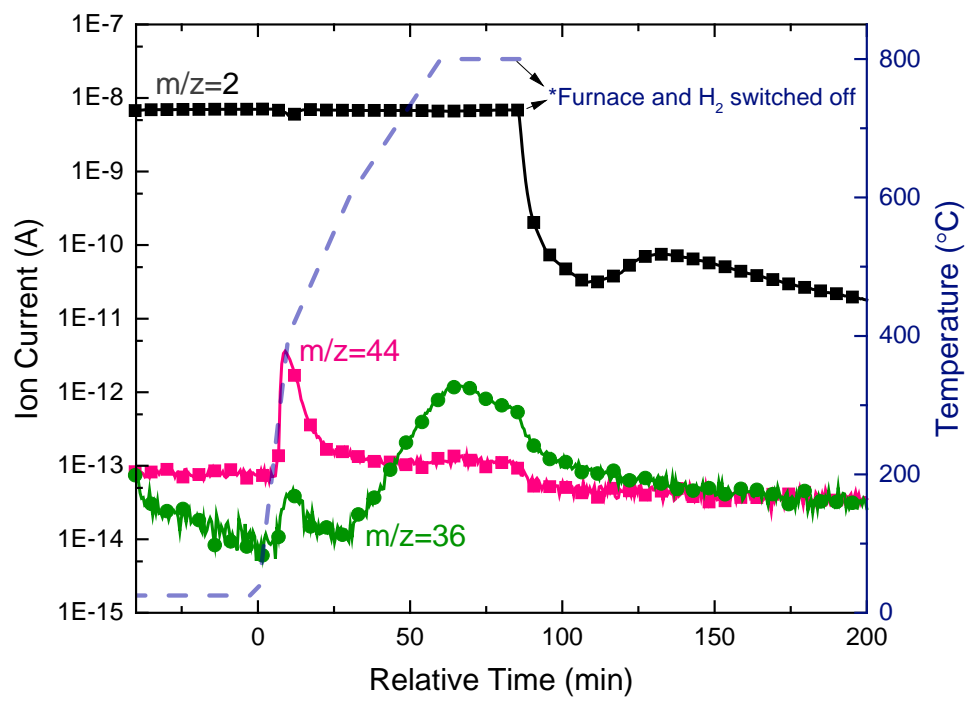

Figure 4. $\mathrm{H}_{2}(\mathrm{~m} / \mathrm{z}=2), \mathrm{CO}_{2}(\mathrm{~m} / \mathrm{z}=44)$ and $\mathrm{HCl}(\mathrm{m} / \mathrm{z}=36)$ detected by the mass spectrometer (MS) during the annealing of $\mathrm{Pt} / \mathrm{C}$ nanoparticles and $\mathrm{YCl}_{3}$ at $800^{\circ} \mathrm{C}$ in a $\mathrm{H}_{2}$ atmosphere. The dotted lines are related to the ion current measured by the MS (left axis) and the dashed line is related to the temperature of the furnace (right axis). 
A) $\mathrm{Pt}_{\mathrm{x}} \mathrm{Y} / \mathrm{C}$ nanoparticles $\left(360 \mathrm{~min}\right.$ at $\left.800^{\circ} \mathrm{C}\right)$
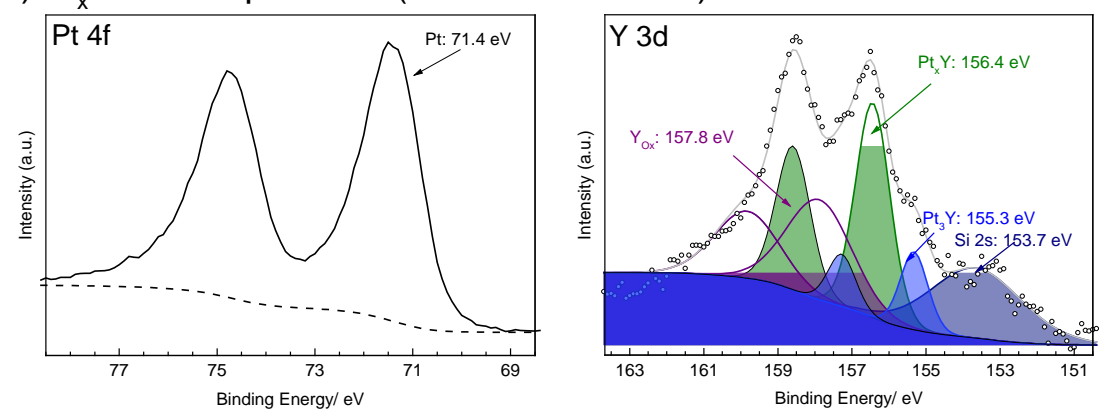

B) $\mathrm{Pt}_{\mathrm{x}} \mathrm{Y} / \mathrm{C}$ nanoparticles $\left(60 \mathrm{~min}\right.$ at $\left.800^{\circ} \mathrm{C}\right)$
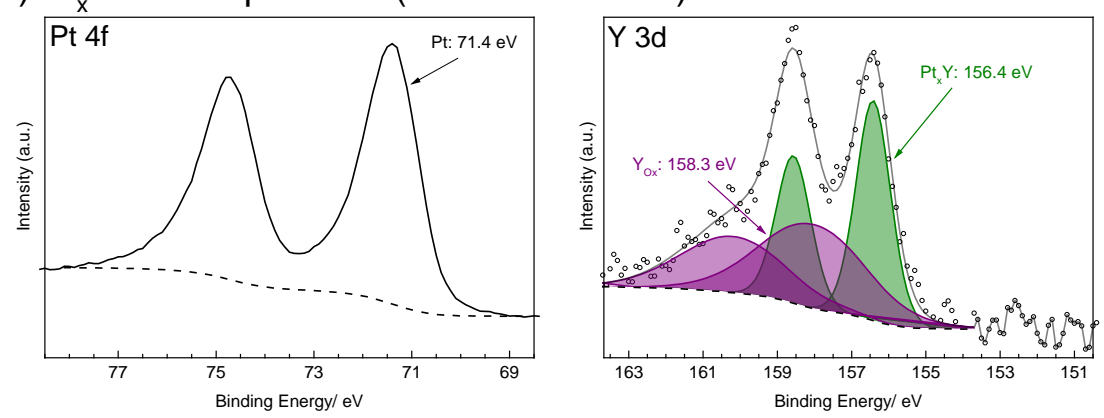

Figure 5. XPS spectra in the platinum $4 \mathrm{f}$ and yttrium $3 d$ core level regions for $\mathrm{Pt}_{\mathrm{x}} \mathrm{Y}$ obtained from (A) 360 and (B) 60 minutes annealing at $800^{\circ} \mathrm{C}$. The catalysts were acid $(0.1 \mathrm{M}$ $\mathrm{HClO}_{4}$ ) and water washed 3 times before XPS measurements. 


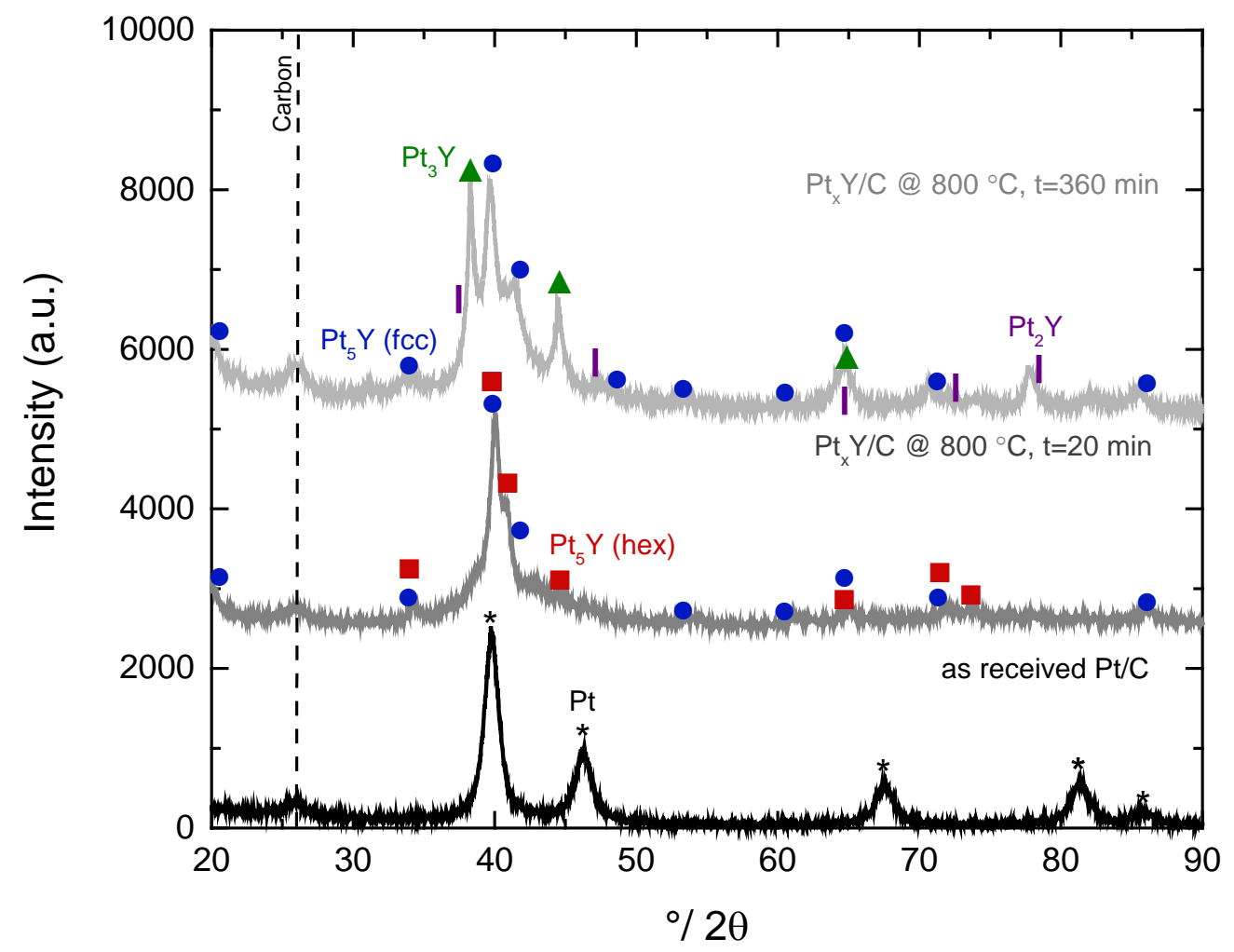

Figure 6. XRD patterns of as received $\mathrm{Pt} / \mathrm{C}$ (black line), $\mathrm{Pt}_{\mathrm{x}} \mathrm{Y} / \mathrm{C}$ (30 min) (dark grey) and $\mathrm{Pt}_{\mathrm{x}} \mathrm{Y} / \mathrm{C}$ (360 min) (light grey) nanoparticles. 
A) $\mathrm{Pt} / \mathrm{C}$ nanoparticles

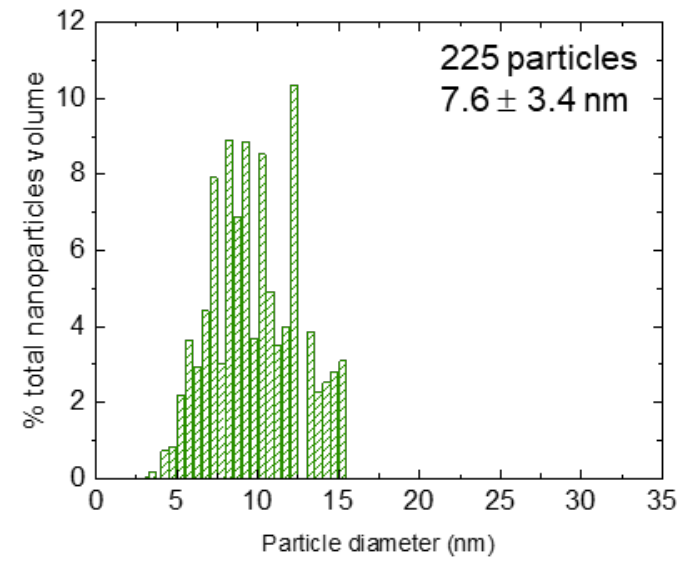

B) PtxY/C nanoparticles $\left(60 \mathrm{~min}\right.$ at $\left.800^{\circ} \mathrm{C}\right)$

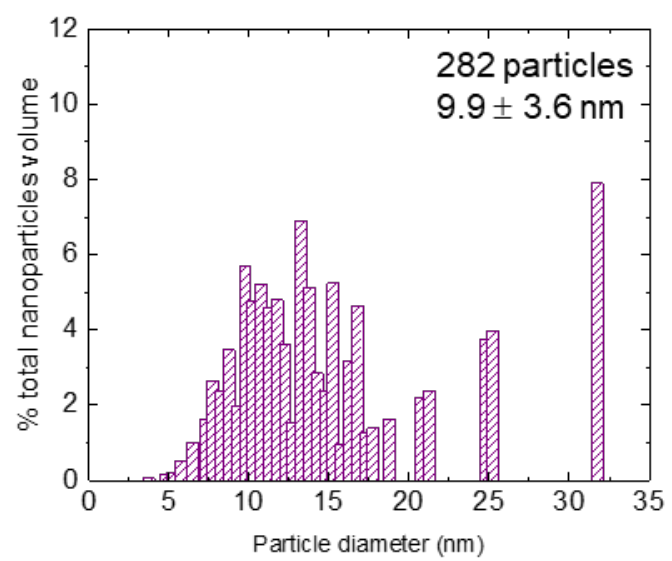

C) PtxY/C nanoparticles $\left(360 \mathrm{~min}\right.$ at $\left.800^{\circ} \mathrm{C}\right)$

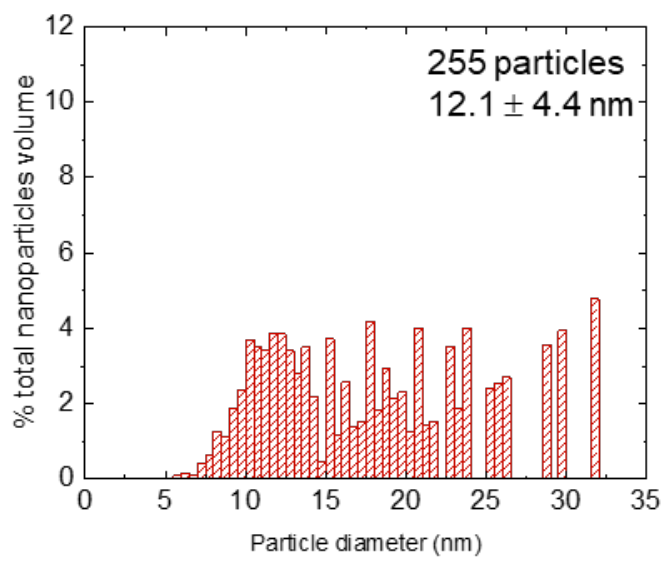

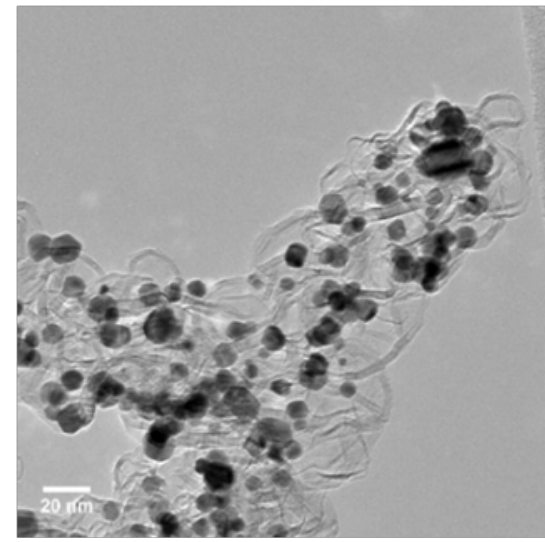
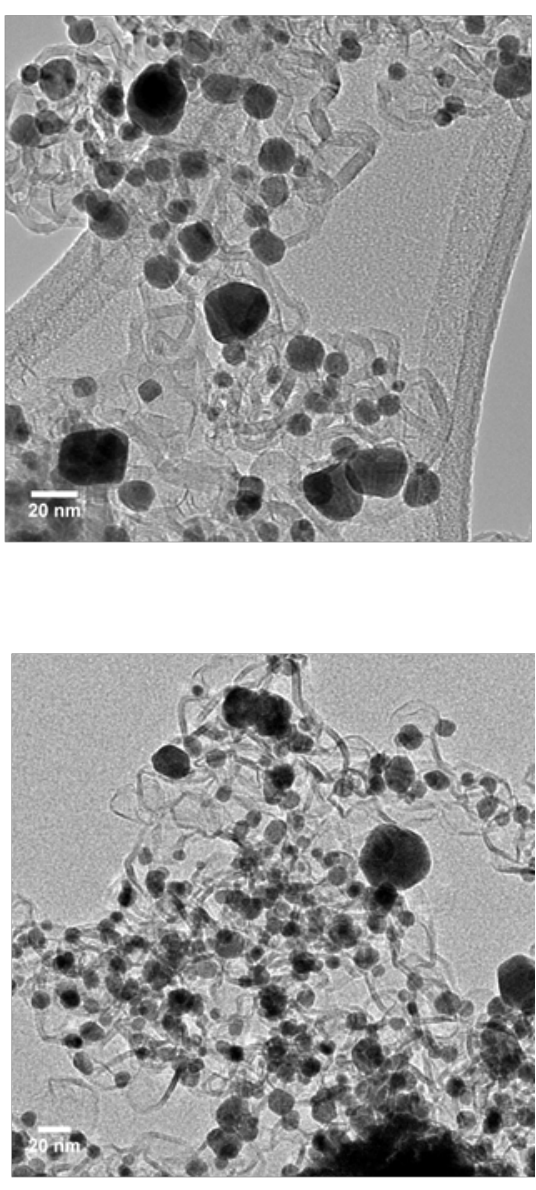

Figure 7. Particle size distributions and representative TEM micrographs for the A) as received Pt/C, B) 30 min annealed @800 ${ }^{\circ} \mathrm{C} t_{\mathrm{x}} \mathrm{Y} / \mathrm{C}$ and C) 360 min annealed @800 ${ }^{\circ} \mathrm{Pt} \mathrm{x}_{\mathrm{x}} \mathrm{Y} / \mathrm{C}$ 

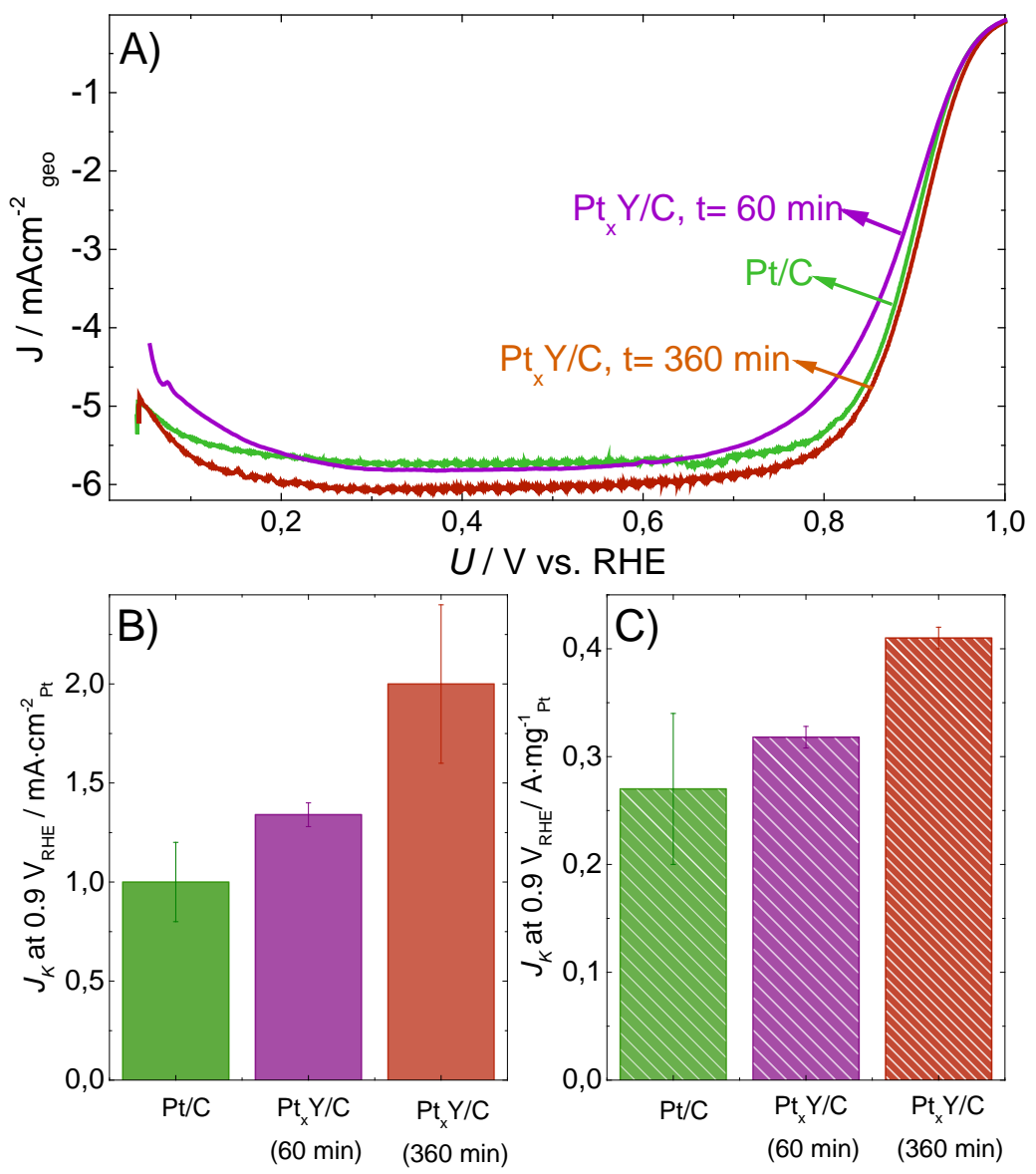

Figure 8. A) RRDE polarization curves at $1600 \mathrm{rpm}$ and $50 \mathrm{mV} \mathrm{s}^{-1}$ for the ORR on $\mathrm{Pt} / \mathrm{C}$ (green curve), $\mathrm{Pt}_{\mathrm{x}} \mathrm{Y} / \mathrm{C}\left(60 \mathrm{~min}\right.$ at $800^{\circ} \mathrm{C}$ ) (purple curve), and $\mathrm{Pt}_{\mathrm{x}} \mathrm{Y} / \mathrm{C}\left(360 \mathrm{~min}\right.$ at $800^{\circ} \mathrm{C}$ ) (red curve) nanoparticles catalysts in $\mathrm{O}_{2}$-saturated $0.1 \mathrm{M} \mathrm{HClO}_{4}$. Kinetic current density normalized by (A) specific surface area and (B) mass of $\mathrm{Pt}$ at $0.9 \mathrm{~V}_{\mathrm{RHE}}$ for $\mathrm{Pt} / \mathrm{C}$ and $\mathrm{Pt}_{\mathrm{X}} \mathrm{Y} / \mathrm{C}$ annealed for 30 and 360 min at $800^{\circ} \mathrm{C}$, based on data from $\mathrm{A}$ ). 


\section{AUTHOR INFORMATION}

\section{Corresponding Author}

Professor Dr. Ib Chorkendorff

e-mail: ibchork@fysik.dtu.dk

\section{Author Contributions}

The manuscript was written through contributions of all authors. All authors have given approval to the final version of the manuscript.

\section{Funding Sources}

This work was supported by a research grant (9455) from VILLUM FONDEN. We also acknowledge UPCAT under the project no. 2015-1-12315.

\section{ACKNOWLEDGMENT}

This work was supported by a research grant (9455) from VILLUM FONDEN. We also acknowledge UPCAT under the project no. 2015-1-12315. The authors would like to thank Jakob Kibsgaard for drawing the schematic of the setup presented in Figure 2. 


\section{REFERENCES}

(1) H. A. Gasteiger and J. Garche. Handbook of Heterogeneous Catalysis; G. Ertl, H. Knözinger, J. W., Ed.; Wiley-VCH Verlag GmbH \& Co, 2008.

(2) Wayne Reitz. Mater. Manuf. Processes, 22nd ed.; 2007.

(3) Stephens, I. E. L.; Bondarenko, A. S.; Bech, L.; Chorkendorff, I. ChemCatChem 2012, 4 (3), 341-349.

(4) Stephens, I. E. L.; Bondarenko, A. S.; Grønbjerg, U.; Rossmeisl, J.; Chorkendorff, I. Energy Environ. Sci. 2012, 5 (5), 6744.

(5) Hong, W. T.; Risch, M.; Stoerzinger, K. A.; Grimaud, A.; Suntivich, J.; Shao-Horn, Y. Energy Environ. Sci. 2015, 8 (5), 1404-1427.

(6) Jan Rossmeisl, Gustav S. Karlberg, Thomas Jaramillo, and J. K. N. Faraday Discuss. 2008, 140, 337-346.

(7) Tripković, V.; Skúlason, E.; Siahrostami, S.; Nørskov, J. K.; Rossmeisl, J. Electrochim. Acta 2010, 55 (27), 7975-7981.

(8) Han, B.; Carlton, C. E.; Kongkanand, A.; Kukreja, R. S.; Theobald, B. R.; Gan, L.; O’Malley, R.; Strasser, P.; Wagner, F. T.; Shao-Horn, Y. Energy Environ. Sci. 2015, 8 (1), 258-266.

(9) Cui, C.; Gan, L.; Heggen, M.; Rudi, S.; Strasser, P. Nat. Mater. 2013, 12 (8), 765-771.

(10) Chen, C.; Kang, Y.; Huo, Z.; Zhu, Z.; Huang, W.; Xin, H. L.; Snyder, J. D.; Li, D.; Herron, J. A.; Mavrikakis, M.; Chi, M.; More, K. L.; Li, Y.; Markovic, N. M.; Somorjai, G. A.; Yang, P.; Stamenkovic, V. R. Science. 2014, 343 (6177), 1339-1343.

(11) Yoshida, T.; Kojima, K. Interface Mag. 2015, 24 (2), 45-49.

(12) Chen, S.; Gasteiger, H. A.; Hayakawa, K.; Tada, T.; Shao-Horn, Y. J. Electrochem. Soc. 2010, 157 (1), A82.

(13) Maillard, F.; Dubau, L.; Durst, J.; Chatenet, M.; André, J.; Rossinot, E. Electrochem. commun. 2010, 12 (9), 1161-1164.

(14) Dubau, L.; Lopez-Haro, M.; Castanheira, L.; Durst, J.; Chatenet, M.; Bayle-Guillemaud, P.; Guétaz, L.; Caqué, N.; Rossinot, E.; Maillard, F. Appl. Catal. B Environ. 2013, 142-143, 801-808.

(15) Mayrhofer, K. J. J.; Hartl, K.; Juhart, V.; Arenz, M. J. Am. Chem. Soc. 2009, 131 (45), 16348-16349.

(16) Huang, X.; Zhao, Z.; Cao, L.; Chen, Y.; Zhu, E.; Lin, Z.; Li, M.; Yan, A.; Zettl, A.; Wang, Y. M.; Duan, X.; Mueller, T.; Huang, Y. Science. 2015, 348 (2009), 1230-1234.

(17) Baldizzone, C.; Mezzavilla, S.; Carvalho, H. W. P.; Meier, J. C.; Schuppert, A. K.; Heggen, M.; Galeano, C.; Grunwaldt, J. D.; Schüth, F.; Mayrhofer, K. J. J. Angew. Chemie - Int. Ed. 2014, 53 (51), 14250-14254.

(18) Greeley, J.; Stephens, I. E. L.; Bondarenko, a S.; Johansson, T. P.; Hansen, H. a; Jaramillo, T. F.; Rossmeisl, J.; Chorkendorff, I.; Nørskov, J. K. Nat. Chem. 2009, 1 (7), 552-556. 
(19) Malacrida, P.; Escudero-Escribano, M.; Verdaguer-Casadevall, A.; Stephens, I. E. L.; Chorkendorff, I. J. Mater. Chem. A 2014, 2 (12), 4234.

(20) Escudero-Escribano, M.; Malacrida, P.; Hansen, M. H.; Vej-Hansen, U. G.; VelazquezPalenzuela, A.; Tripkovic, V.; Schiotz, J.; Rossmeisl, J.; Stephens, I. E. L.; Chorkendorff, I. Science. 2016, 352 (6281), 73-76.

(21) Escudero-Escribano, M.; Verdaguer-Casadevall, A.; Malacrida, P.; Grønbjerg, U.; Knudsen, B. P.; Jepsen, A. K.; Rossmeisl, J.; Stephens, I. E. L.; Chorkendorff, I. J. Am. Chem. Soc. 2012, 134 (40), 16476-16479.

(22) Ulrikkeholm, E. T.; Pedersen, A. F.; Vej-Hansen, U. G.; Escudero-Escribano, M.; Stephens, I. E. L.; Friebel, D.; Mehta, A.; Schiøtz, J.; Feidenhansl, R. K.; Nilsson, A.; Chorkendorff, I. Surf. Sci. 2016, 652, 114-122.

(23) Johansson, T. P.; Ulrikkeholm, E. T.; Hernandez-Fernandez, P.; Escudero-Escribano, M.; Malacrida, P.; Stephens, I. E. L.; Chorkendorff, I. Phys. Chem. Chem. Phys. 2014, 16 (27), 13718-13725.

(24) Velázquez-palenzuela, A.; Masini, F.; Pedersen, A. F.; Escudero-escribano, M.; Deiana, D.; Malacrida, P.; Hansen, T. W.; Friebel, D.; Nilsson, A.; Stephens, I. E. L.; Chorkendorff, I. 2015, 328, 297-307.

(25) Hernandez-Fernandez, P.; Masini, F.; McCarthy, D. N.; Strebel, C. E.; Friebel, D.; Deiana, D.; Malacrida, P.; Nierhoff, A.; Bodin, A.; Wise, A. M.; Nielsen, J. H.; Hansen, T. W.; Nilsson, A.; Stephens, I. E. L.; Chorkendorff, I. Nat. Chem. 2014, 6 (8), 732-738.

(26) Velázquez-Palenzuela, A.; Masini, F.; Pedersen, A. F.; Escudero-Escribano, M.; Deiana, D.; Malacrida, P.; Hansen, T. W.; Friebel, D.; Nilsson, A.; Stephens, I. E. L.; Chorkendorff, I. J. Catal. 2015, 328, 297-307.

(27) Lide, D. R. CRC Handbook of Chemistry and Physics; 2005.

(28) Tsuji, M.; Uto, K.; Nagami, T.; Muto, A.; Fukushima, H.; Hayashi, J. ChemCatChem 2017, 9 (6), 962-970.

(29) Cui, R.; Mei, L.; Han, G.; Chen, J.; Zhang, G.; Quan, Y. Sci. Rep. 2017, 7 (41826).

(30) Brandiele, R.; Durante, C.; Grądzka, E.; Rizzi, G. A.; Zheng, J.; Badocco, D.; Centomo, P.; Pastore, P.; Granozzi, G.; Gennaro, A. J. Mater. Chem. A 2016, 4 (31), 12232-12240.

(31) Han, S. B.; Kwak, D. H.; Lee, Y. W.; Kim, S. J.; Lee, J. Y.; Lee, S.; Kwon, H. J.; Park, K. W. Int. J. Electrochem. Sci. 2016, 11 (5), 3803-3814.

(32) Yoo, S. J.; Lee, K.-S.; Hwang, S. J.; Cho, Y.-H.; Kim, S.-K.; Yun, J. W.; Sung, Y.-E.; Lim, T.-H. Int. J. Hydrogen Energy 2012, 37 (12), 9758-9765.

(33) Jeon, M. K.; McGinn, P. J. J. Power Sources 2011, 196 (3), 1127-1131.

(34) Hyun, K.; Lee, J. H.; Yoon, C. W.; Kwon, Y. Int. J. Electrochem. Sci. 2013, 8, 1175211767.

(35) Kanady, J. S.; Leidinger, P.; Haas, A.; Titlbach, S.; Schunk, S.; Schierle-Arndt, K.; Crumlin, E. J.; Wu, C. H.; Alivisatos, A. P. J. Am. Chem. Soc. 2017, 139 (16), 5672-5675.

(36) Yan, C.; Wagner, M. J. Nano Lett. 2013, 13 (6), 2611-2614.

(37) Lux, K. W.; Cairns, E. J. J. Electrochem. Soc. 2006, 153 (6), A1132. 
(38) Kleykamp, H. J. Nucl. Mater. 1993, 201 (C), 193-217.

(39) Hellwig, L. Thermodynamische Untersuchungen an den Systemen Yttrium-Platin und Neptunium-Platin durch EMK-Messungen mit galvanischen Festkörperketten; Kernforscungszentrum Karlsruhe, 1978.

(40) Erdmann, B. "Darstellung von Actiniden-Lanthaniden-Edelmetall (Pt, Pd, Ir, Rh)Legierungsphasen durch gekoppelte Reduktion; 1971.

(41) Keller, C.; Erdmann, B. J. Solid State Chem. 1973, 7, 40-48.

(42) Mayrhofer, K. J. J.; Strmcnik, D.; Blizanac, B. B.; Stamenkovic, V.; Arenz, M.; Markovic, N. M. Electrochim. Acta 2008, 53 (7), 3181-3188.

(43) Pedersen, C. M.; Escudero-escribano, M.; Velázquez-Palenzuela, A.; Christensen, L. H.; Chorkendorff, I.; Stephens, I. E. L. Electrochim. Acta 2015, 179, 1-11.

(44) Stamenković, V.; Schmidt, T. J.; Ross, P. N.; Marković, N. M. J. Electroanal. Chem. 2003, 554-555 (1), 191-199.

(45) Garsany, Y.; Baturina, O. a; Swider-Lyons, K. E.; Kocha, S. S. Anal. Chem. 2010, 82 (15), 6321-6328.

(46) Čolić, V.; Tymoczko, J.; Maljusch, A.; Ganassin, A.; Schuhmann, W.; Bandarenka, A. S. ChemElectroChem 2015, 2, 143-149.

(47) Binninger, T.; Fabbri, E.; Kotz, R.; Schmidt, T. J. J. Electrochem. Soc. 2013, 161 (3), H121H128.

(48) Savinova, E. R.; Stimming, U. J. Electroanal. Chem. 2007, 599, 221-232.

(49) Perez-alonso, F. J.; Mccarthy, D. N.; Nierhoff, A.; Hernandez-fernan-, P.; Strebel, C.; Stephens, I. E. L.; Nielsen, J. H.; Chorkendorff, I. Angew. Commun. 2012, 51, 4641-4643.

(50) Kongkanand, A.; Mathias, M. F. J. Phys. Chem. Lett. 2016, 7 (7), 1127-1137.

(51) Zalitis, C. M.; Kramer, D.; Kucernak, A. R. Phys. Chem. Chem. Phys. 2013, 15 (12), 4329.

(52) Stephens, I. E. L.; Rossmeisl, J.; Chorkendorff, I. Science. 2016, 354 (6318), 1378-1379. 